\title{
Importance of parental effects on larval survival in Sardina pilchardus
}

\author{
I. Riveiro ${ }^{1, *}$, C. Guisande ${ }^{1}$, M. Lloves ${ }^{1}$, I. Maneiro ${ }^{1}$, J. M. Cabanas ${ }^{2}$ \\ ${ }^{1}$ Facultad de Ciencias del Mar, Universidad de Vigo, Aptdo. 874, 36200 Vigo, Spain \\ ${ }^{2}$ Instituto Español de Oceanografía, Centro Costero de Vigo, Aptdo. 1552, 36280 Vigo, Spain
}

\begin{abstract}
A combined field and laboratory study was carried out to determine the importance of parental effects (spatial and temporal variations in spawning, egg size and biochemical composition of the egg) on larval survival in Sardina pilchardus. Egg abundance was positively correlated with

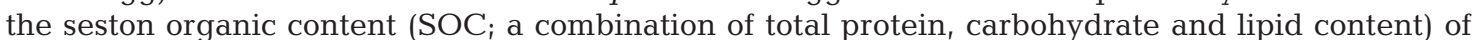
the size particle fraction 20 to $1000 \mu \mathrm{m}$. This was interpreted as a reproductive strategy, to spawn more eggs in areas and during periods of enhanced food availability to larvae. Larval survival under starvation conditions was related to temperature, but only when just the larvae in which the yolk-sac was fully absorbed at death were considered. However, if larval survival time was estimated considering all larvae, including those which died before yolk-sac absorption, larval survival time was related to the biochemical composition of the egg. Larval survival time increased as the percentage of protein in the egg increased, indicating the importance of protein under food limiting conditions. Furthermore, percentage of larvae with yolk-sac completely absorbed at death was higher as egg protein percentage increased. Although producing eggs with a higher proportion of proteins in response to diminishing food availability could maximise larval success under starvation conditions, this parental strategy was not exhibited by $S$. pilchardus. There was not a significant relationship between egg protein percentage and SOC. Biochemical composition of the egg seemed to vary according to temperature of the water.
\end{abstract}

KEY WORDS: Sardina pilchardus $\cdot$ Eggs $\cdot$ Survival $\cdot$ Temperature $\cdot$ Food concentration $\cdot$ Biochemical composition · Starvation $\cdot$ Upwelling

\section{INTRODUCTION}

The different strategies exhibited by fish populations to increase egg and larval survival may be defined as parental effects. These strategies include spatial and temporal variations in spawning intensity, egg size, yolk volume and egg quality.

Spatial and temporal variability in spawning intensity may affect survival since eggs spawned at different times of day or year, or at different locations, may be exposed to different sources and magnitudes of mortality due to predation, light intensity, feeding conditions, etc. (see Ribeiro et al. 1996). Temporal variabil-

\footnotetext{
*E-mail: iriveiro@uvigo.es
}

ity in spawning intensity of sardine in the Iberian peninsula has been shown to be an important factor in minimising the loss of larvae offshore (Robles et al. 1992). Oceanic or coastal spawning grounds of fish are often distant from nursery areas. Fish larvae require appropriate currents and sufficient and suitable food during transit to reach the nursery areas at the proper time, size and condition. Parrish et al. (1981) hypothesised that deviations from 'normal' transport conditions (upwelling and offshore transport) could have profound detrimental effects on a year class by carrying eggs and larvae to areas where there is not enough food to survive.

Egg size may determine larval size and yolk volume at hatching (Baynes \& Howell 1996, Kristjánsson \& Vøllestad 1996, Pepin et al. 1997). However, it has 
been observed that egg viability and larval fitness can also be determined by the biochemical composition of the egg (Srivastava \& Brown 1991, MacKenzie et al. 1996, Pickova et al. 1997).

Although a great amount of work exists on egg biochemical composition, most studies focus on variability in biochemical composition of developing fish eggs and larvae (Rønnestad et al. 1992, Finn et al. 1995, 1996, Rainuzzo et al. 1997) and how biochemical composition of the egg affects vertical distribution of eggs in the water column (Craik \& Harvey 1987 , Nissling \& Vallin 1996, Thorsen et al. 1996, Guisande et al. 1998).

During the transition to exogenous feeding, the amount of yolk remaining and its composition may be important. Starvation is suggested to be one of the major causes of mortality during the period when larvae change from endogenous to exogenous feeding (Canino et al. 1991, Bailey et al. 1995) and has been proposed as a primary agent of mortality in all early larvae (Bisbal \& Bengtson 1995, Clemmensen et al. 1997, Jonas \& Wahl 1998). However, the significance of starvation in larval mortality can be variable depending on the species and location studied (Theilacker 1986, Bestgen 1996, Theilacker et al. 1996, Rooker et al. 1997, Chícharo 1998, Chícharo et al. 1998).

Larval condition and therefore mortality under food-limiting conditions may also depend on the previous biochemical composition of eggs. While some studies have been conducted to test the importance of egg biochemical composition on larval survival (Srivastava \& Brown 1991, Brown \& Taylor 1992), they were carried out on eggs that were artificially fertilised in culture tanks. Little is known about what happens under natural conditions. Because the amount of yolk in the egg affects the time that larvae can survive without food, the effect of temperature on absorption rate must also be considered when relating larval survival to egg quality (Hart \& Purser 1995, Kucharczyk et al. 1997).

Our aim was to carry out a field study to determine whether Sardina pilchardus exhibits any parental strategy to maximise larval survival time. From all possible parental strategies we focused the study on the variations in spatial and temporal spawning intensity, egg size, yolk volume and egg quality.

\section{METHODS}

Field study. From February 1998 to June 1999 fertilised Sardina pilchardus eggs were collected monthly along the Ria de Vigo (NW Spain) in the RV 'Jose María Navaz' at 4 stations: $11\left(42^{\circ} 7.8^{\prime} \mathrm{N}, 9^{\circ} 7.5^{\prime} \mathrm{W}\right.$;

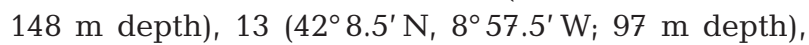

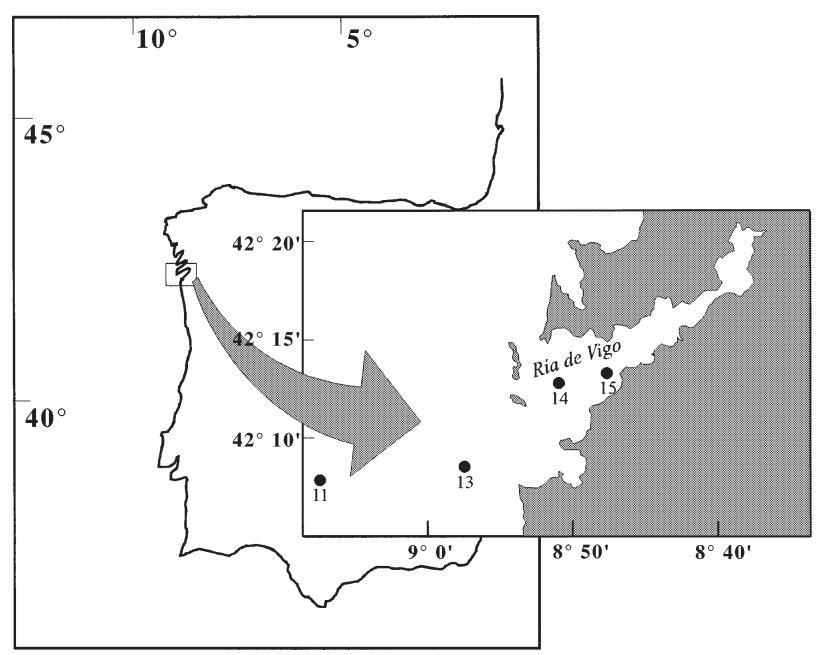

Fig. 1. Map of the study area showing location of sampling stations

$14\left(42^{\circ} 12.8^{\prime} \mathrm{N}, 8^{\circ} 51^{\prime} \mathrm{W} ; 39 \mathrm{~m}\right.$ depth) and $15\left(42^{\circ} 13.3^{\prime} \mathrm{N}\right.$, $8^{\circ} 47.7^{\prime} \mathrm{W} ; 29 \mathrm{~m}$ depth) (Fig. 1).

Samples were collected by a $50 \mathrm{~cm}$ diameter Bongo sampler fitted with $335 \mu \mathrm{m}$ mesh aperture nets, towed obliquely from about $5 \mathrm{~m}$ off the bottom to the surface at approximately 2 knots. Volumes filtered were obtained from flowmeters positioned in the mouth of the nets. Each sample was transported to the laboratory in 301 of seawater, where samples were analysed within $4 \mathrm{~h}$ of collection.

In order to know the quantity and quality of the seston, vertical net hauls using a $20 \mu \mathrm{m}$ mesh net (equipped with flowmeter) were towed at each station from the same depth as the egg samples. The fraction 20 to $1000 \mu \mathrm{m}$ was resuspended in 11 of filtered seawater then subsamples taken for subsequent biochemical analyses.

CTD (Seabird 25) profiles were carried out at all stations. An upwelling index was calculated using the method described by Bakun (1973), which has been used before in the Galician coast by Lavin et al. (1991).

Survival time study. Larval survival time was performed on eggs collected in 1998. In the laboratory, eggs were identified and measured using a binocular microscope fitted with an ocular micrometer. Subsequently, eggs were placed individually in assay tubes with $10 \mathrm{ml}$ of filtered seawater (from the stations where eggs were collected) through $0.45 \mu \mathrm{m}$ of GF/F (glass microfibre filters) and stored at different temperatures $\left(9,12,15\right.$ and $\left.18^{\circ} \mathrm{C}\right)$ under a 12:12 h light:dark cycle. Every month, the number of eggs incubated at each temperature ranged between 4 and 20. Eggs were inspected every $6 \mathrm{~h}$ to record hatching time and time when larvae died. Larval death was determined using a binocular microscope. 
Biochemical analysis. When sufficient eggs were collected they were analysed for protein, carbohydrate and lipid content. After staging and measuring, 2 eggs of similar size and at the same developmental stage were transferred to an ultracentrifuge plastic tube with $600 \mu l$ of bidistilled water. Samples were homogenised using a pipette tip adapted to fit the shape of the vial. $200 \mu \mathrm{l}$ of each egg homogenate were used for protein analysis, $200 \mu \mathrm{l}$ for carbohydrate analysis and $75 \mu \mathrm{l}$ for lipid analysis. Every month the number of replicates, with 2 eggs in each, ranged between 16 and 43, with the exception of December 1998 when there were only 3 replicates.

The method describe by Lowry et al. (1951) and modified by Maxwell et al. (1978) was used to analyse the protein content of the eggs. To $200 \mu \mathrm{l}$ sample volumes, $50 \mu \mathrm{l}$ of $\mathrm{NaOH}(0.5 \mathrm{~N})$ (prepared just before the test) and $750 \mu \mathrm{l}$ of solution $\mathrm{C}$ were added. Solution $\mathrm{C}$ was prepared shortly before the beginning of the analysis and was composed of Solutions A and B in a proportion of 100A:1B. These solutions were as follows: 'Solution A', $\mathrm{Na}_{2} \mathrm{CO}_{3}(2 \%), \mathrm{NaOH}(0.4 \%), \mathrm{NaK}$ $(\mathrm{COO})_{2}(\mathrm{CHOH})_{2} 4 \mathrm{H}_{2} \mathrm{O}(0.16 \%)$, SDS $(1 \%)_{i}$ 'Solution B', $\mathrm{CuSO}_{4} 5 \mathrm{H}_{2} \mathrm{O}(4 \%)$. The samples were shaken and maintained at $30^{\circ} \mathrm{C}$ for $15 \mathrm{~min}$. Then $75 \mu \mathrm{l}$ of diluted 1:1 Folin-Cioccalteus were added to each sample. Subsequently, the samples were incubated for $30 \mathrm{~min}$ at the same temperature. Absorbance was read at $660 \mathrm{~nm}$ and compared with bovine serum albumin (BSA) standard.

Egg carbohydrate content was measured by the phenol-sulphuric acid method (Dubois et al. 1956). To sample $200 \mu \mathrm{l}$ of homogenate and $200 \mu \mathrm{l}$ of bidistilled water, $10 \mu \mathrm{l}$ of $81 \%$ phenol was added and, after gently shaking, $1 \mathrm{ml}$ of concentrated sulphuric acid was added. The sample was shaken again and maintained at room temperature for $30 \mathrm{~min}$. Finally, the absorbance was read at $485 \mathrm{~nm}$. A standard curve was established using reagent-grade glucose.

Egg lipid content was determined using the sulfophosphovanillin method (Zöllner \& Kirsch 1962). $50 \mu \mathrm{l}$ of absolute ethanol was added to $75 \mu \mathrm{l}$ of homogenate, immediately after which the sample was shaken and maintained at $4^{\circ} \mathrm{C}$ for at least $2 \mathrm{~h}$. Then $375 \mu \mathrm{l}$ of concentrated sulphuric acid was added and the sample was homogenised by shaking. The sample was then maintained at $100^{\circ} \mathrm{C}$ for $15 \mathrm{~min}$. After hydrolysis, when the sample had cooled down, $2 \mathrm{ml}$ of vanillin reagent $(1.976 \mathrm{~g}$ of vanillin with $800 \mathrm{ml}$ of $85 \%$ $\mathrm{H}_{3} \mathrm{PO}_{4}$ and distilled water to $1000 \mathrm{ml}$ ) was added. The sample was shaken and incubated at $30^{\circ} \mathrm{C}$ for $30 \mathrm{~min}$, then absorbance was read at $530 \mathrm{~nm}$.

Total protein, carbohydrate and lipid contents of the seston fraction (20 to $1000 \mu \mathrm{m}$ ) were determined using methods analysis described above. The organic content (total protein, carbohydrate and lipid content) of the total seston size fraction 20 to $1000 \mu \mathrm{m}$ was used as an indicator of food potentially available to the larvae. As larval body size of larvae that appear in this area ranged between 2.4 and $28 \mathrm{~mm}$, the seston size fraction measured is within the range of prey captured by larvae of this body size (Conway et al. 1991).

Statistical analyses were made with SPSS 8.0 (1998).

\section{RESULTS}

Sampling station means $( \pm \mathrm{SD})$ of egg size, egg stage, total protein, total carbohydrate, total lipid and organic content of the eggs as well as protein, carbohydrate and lipid percentage of the eggs are given in Table 1. Protein proved to be the most abundant organic component of the eggs with a pooled mean \pm SD of $69.3 \pm 9.6 \%$, whereas carbohydrate and lipid were $15.0 \pm 6.3$ and $15.7 \pm 8.8 \%$ of the total organic content of the egg, respectively. The monthly mean abundance of Sardina pilchardus eggs at Stns 13, 14 and 15 during the sample period is shown in Fig. 2. Eggs were never found at offshore Stn 11. The main spawning season throughout the sampling area was from December to June (Pérez et al. 1985, Solá et al. 1992). Although a smooth peak is generally observed in this area in autumn (Solá et al. 1992), egg abundance was very low in autumn of 1998.

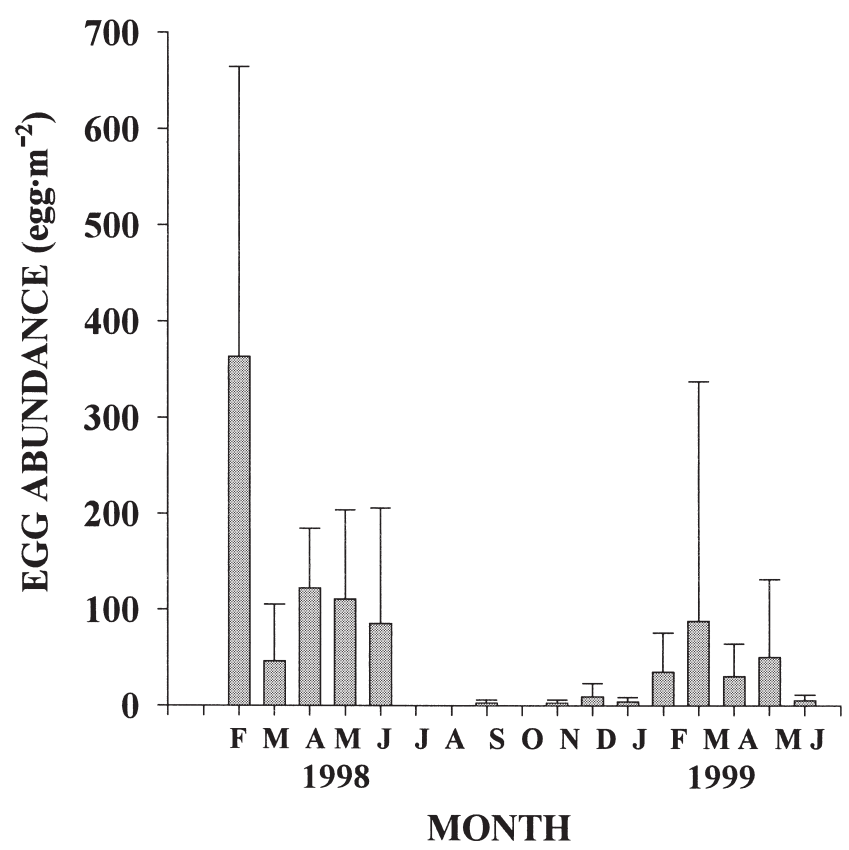

Fig. 2. Sardina pilchardus. Monthly means $( \pm \mathrm{SD})$ of egg abundance at Stns 13,14 and 15 


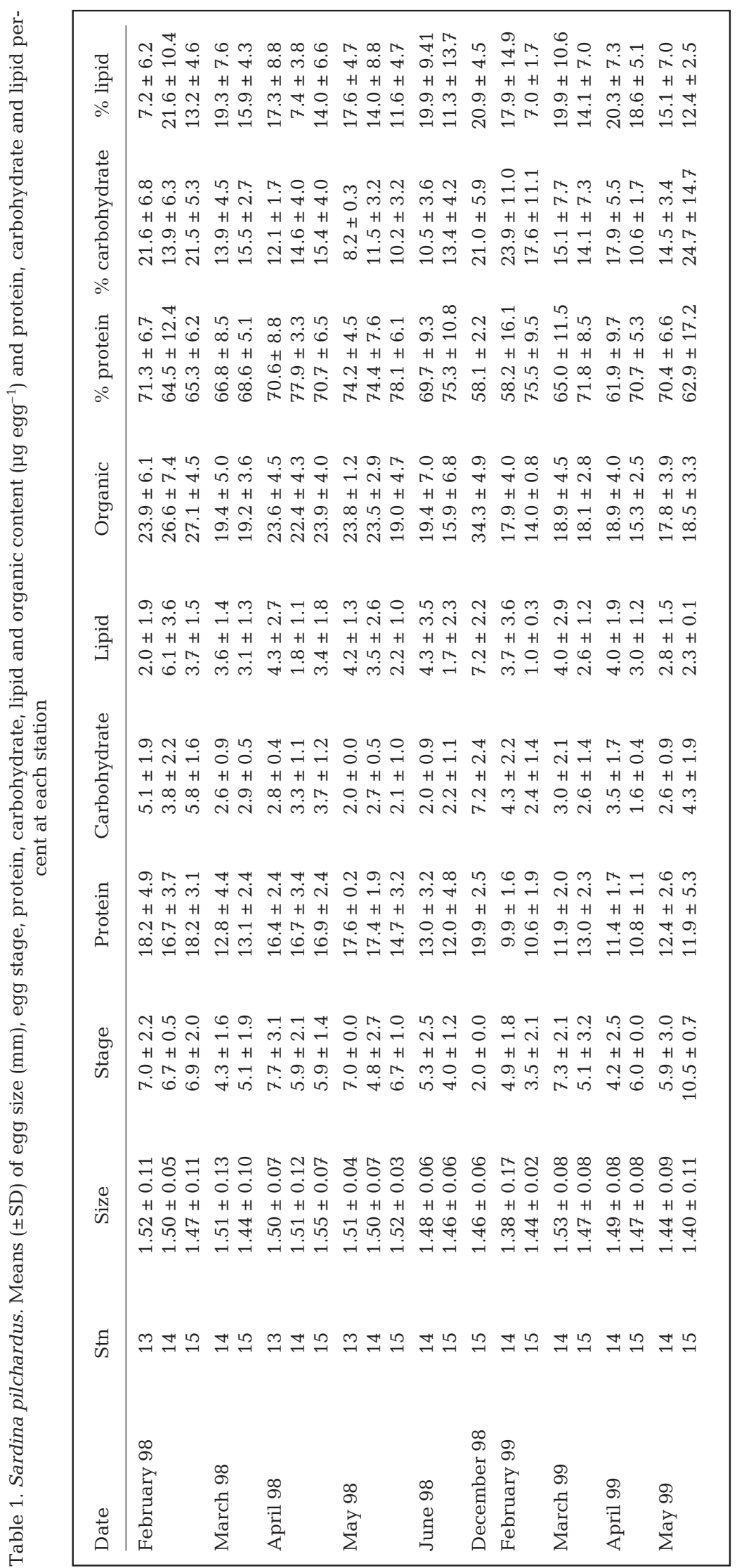

Egg abundance varied significantly both temporally and spatially (Table 2 ). A high proportion of the variation observed in egg abundance was explained by changes in seston organic content (SOC). A stepwise regression showed that considering temperature and $\mathrm{SOC}$, only a significant relationship between SOC and the abundance of eggs was observed (slope different from zero with $\mathrm{p}<0.001, \mathrm{r}^{2}=0.7, F_{1,32}=75.4$; Fig. 3).

When larval survival time at different temperatures was estimated only considering the larvae in which the yolk-sac was fully absorbed at death, a 2-way ANOVA showed that there were not significant differences in larval survival time from hatch to death between months and sampling stations (Table 3). A stepwise regression showed that, considering all the variables (egg size, egg stage, egg biochemical composition and temperature), only temperature was significantly related to larval survival time (Fig. 4; slope different from zero with $\mathrm{p}<0.001$, $\left.\mathrm{r}^{2}=0.94, F_{1,7}=104.9\right)$. February and March 1998 are not shown because all larvae died before yolk-sac absorption in February and only 1 larva died with yolksac fully absorbed in March.

However, larval viability under starvation conditions seems to be also affected by egg biochemical composition. Fig. 5 shows that the percentage of larvae that had a completely absorbed yolk-sac at death was higher as the percentage of egg protein increased (slope different from zero with $\mathrm{p}=0.014, \mathrm{r}^{2}=$ $\left.0.9, F_{1,4}=27.1\right)$. Moreover, larval survival time results were different when all larvae, those in which the yolk-sac was fully absorbed at death and those which died before yolk-sac absorption, were considered. A 2-way ANOVA (Table 4) showed that there were significant differences in larval survival time between the different months but not between the different sampling stations. In this case, a stepwise regression showed that, considering all the variables mentioned above, larval survival time was related to changes in egg protein percentage (slope different from zero with $\mathrm{p}<0.001, \mathrm{r}^{2}=0.77, F_{1,11}=$ 36.2) (Fig. 6). 
Table 2. Sardina pilchardus. Results of ANCOVA of the egg abundance (eggs $\mathrm{m}^{-2}$ ) with sampling station as factor and month as covariate

\begin{tabular}{|lrrrr|}
\hline Source of variation & df & \multicolumn{1}{c}{ MS } & \multicolumn{1}{c}{$F$} & \multicolumn{1}{c|}{ p } \\
\hline Sampling station & 3 & 138924.0 & 3.5 & 0.021 \\
Month & 1 & 47895.4 & 4.2 & 0.044 \\
Interaction & 1 & 39509.1 & 12.3 & 0.001 \\
Error & 63 & 111312.1 & & \\
Total & 68 & & & \\
\hline
\end{tabular}

Table 3. Sardina pilchardus. Summary of 2-way ANOVA comparing larval survival under starvation conditions as a function of sampling station and month. Only larvae in which the yolk-sac had been fully absorbed were considered

\begin{tabular}{|lrrcc|}
\hline Source of variation & df & \multicolumn{1}{c}{ MS } & \multicolumn{1}{c|}{$F$} & $\mathrm{p}$ \\
\hline Sampling station & 2 & 920.7 & 0.3 & 0.743 \\
Month & 2 & 883.1 & 0.3 & 0.752 \\
Interaction & 2 & 583.6 & 0.2 & 0.827 \\
Error & 13 & 3025.7 & & \\
Total & 20 & & & \\
& & & & \\
\hline
\end{tabular}

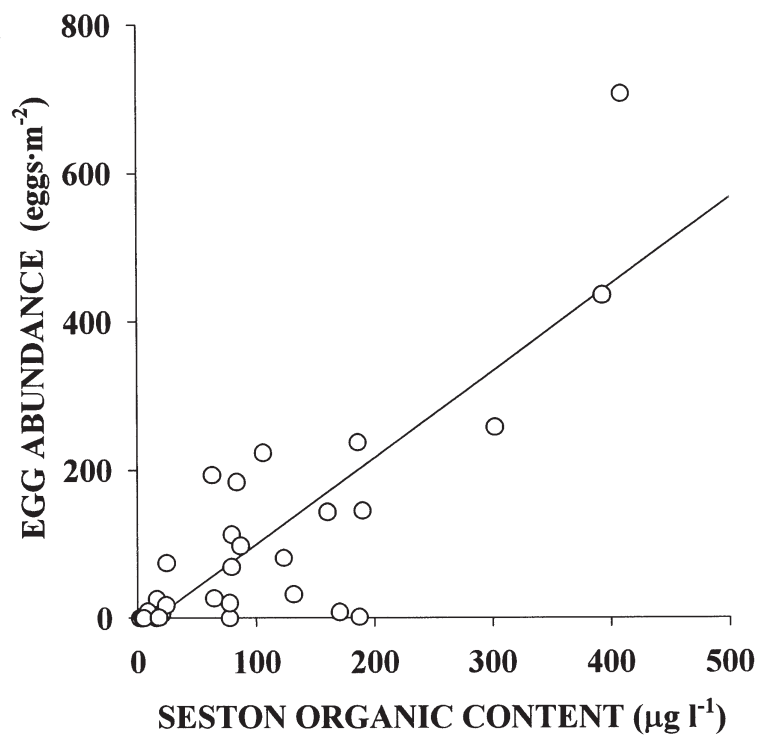

Fig. 3. Sardina pilchardus. Relationship between egg abundance and total organic content of the seston size fraction 20 to $1000 \mu \mathrm{m}$ obtained at the sampling stations

Table 5 shows that egg protein percentage varied significantly between sampling stations and months. However, despite the importance of egg protein percentage on subsequent larval survival time under food-limiting conditions, there was not a significant

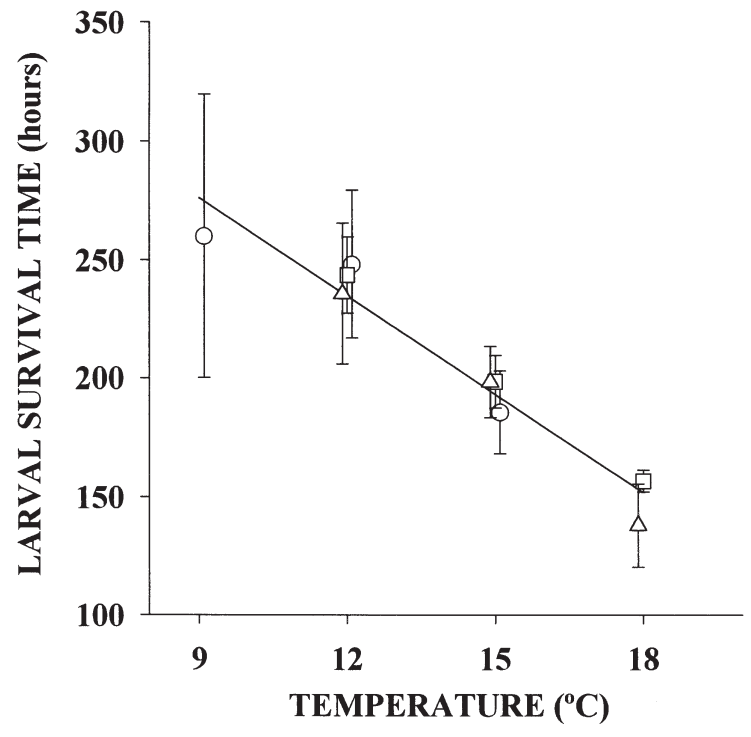

Fig. 4. Sardina pilchardus. Relationship between monthly means $( \pm \mathrm{SE})$ of larval survival (time after hatch) under starvation conditions and temperature from larvae collected in April (O), May ( $\square)$ and June $(\Delta)$ 1998. Larval survival was estimated only considering larvae in which the yolk-sac was fully absorbed

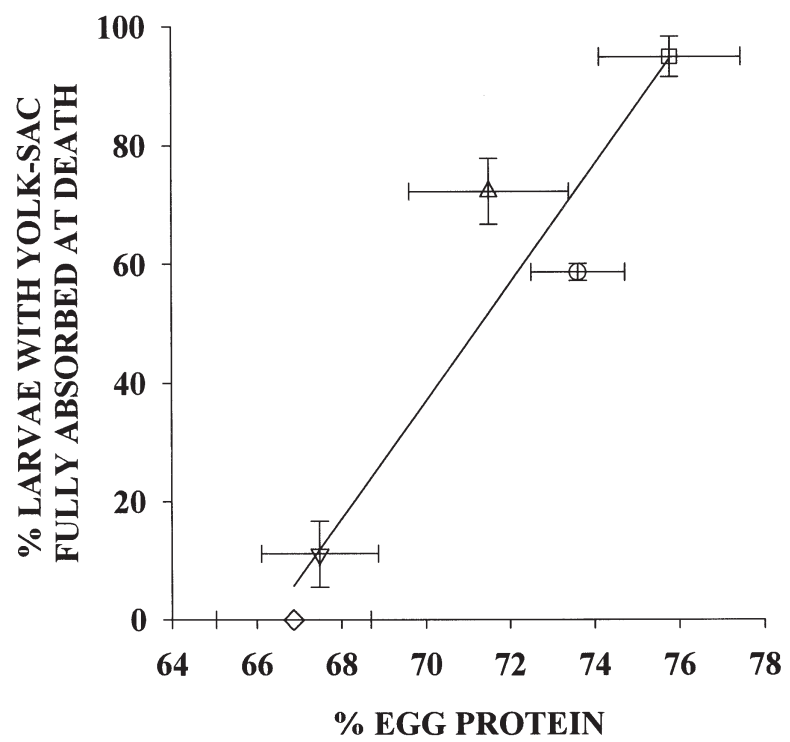

Fig. 5. Sardina pilchardus. Relationship between monthly means $( \pm \mathrm{SE})$ of percentage of larvae with yolk-sac completely absorbed at death under starvation conditions and the percentage of protein in the egg, from larvae collected in February $(\diamond)$, March $(\nabla)$, April $(O)$, May $(\square)$ and June $(\Delta)$ 1998

relationship between egg protein percentage and SOC $\left(\mathrm{p}=0.267, \mathrm{r}^{2}=0.064, F_{1,19}=1.3\right)$. The variation in egg biochemical composition was correlated with changes in the temperature of the water (Fig. 7). A stepwise regression showed that in 1998 the variation in egg 
Table 4. Sardina pilchardus. Summary of 2-way ANOVA comparing larval survival under starvation conditions as a function of sampling station and month. All larvae, whether or not the yolk-sac was absorbed, were considered

\begin{tabular}{|lcrlc|}
\hline Source of variation & df & \multicolumn{1}{c}{ MS } & $F$ & $\mathrm{p}$ \\
\hline Sampling station & 2 & 349.7 & 0.139 & 0.880 \\
Month & 4 & 19192.4 & 7.1 & 0.002 \\
Interaction & 3 & 383.5 & 0.1 & 0.934 \\
Error & 17 & 2717.4 & & \\
Total & 27 & & & \\
& & & & \\
\hline
\end{tabular}

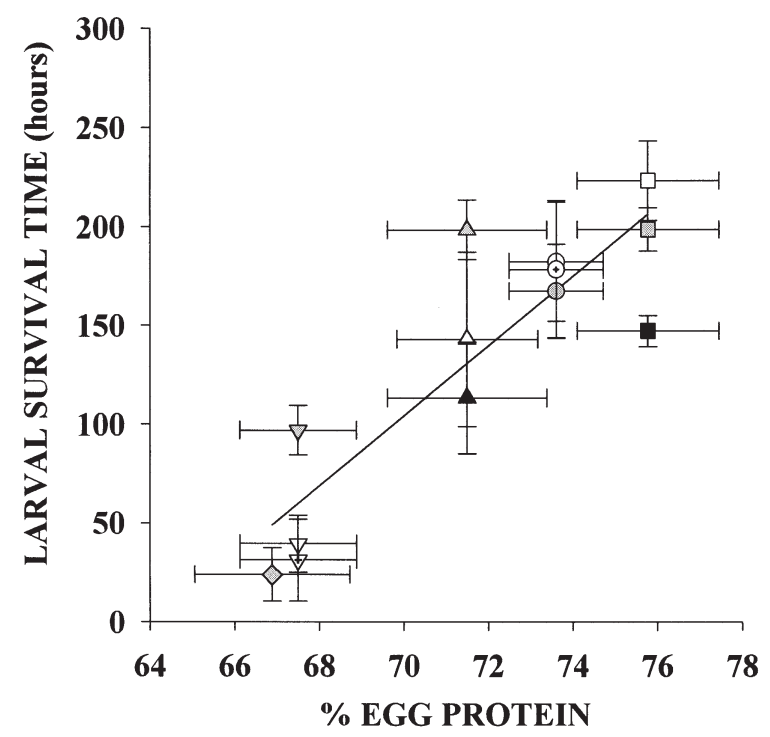

Fig. 6. Sardina pilchardus. Relationship between monthly means $( \pm \mathrm{SE})$ of larval survival (time after hatch) under starvation conditions at different temperatures $\left(9^{\circ} \mathrm{C}\right.$ : symbols with plus, $12^{\circ} \mathrm{C}$ : open symbols, $15^{\circ} \mathrm{C}$ : shaded symbols, and $18^{\circ} \mathrm{C}$ : filled symbols) and the percentage of protein in the egg from larvae collected in February, March, April, May and June 1998. Larval survival was estimated considering all larvae. Symbols same as in Fig. 5

protein percentage was explained by changes in the mean temperature of the water column (slopes different from zero with $\mathrm{p}=0.015, \mathrm{r}^{2}=0.46, F_{1,10}=8.6$ for egg protein percentage and $\mathrm{p}=0.046, \mathrm{r}^{2}=0.34, F_{1,10}=$ 5.2 for egg lipid percentage), but there was not a significant relationship with temperature in 1999 ( $\mathrm{p}=$ $0.817, \mathrm{r}^{2}=0.01, F_{1,7}=0.05$ for egg protein percentage and $\mathrm{p}=0.501, \mathrm{r}^{2}=0.07, F_{1,7}=0.5$ for egg lipid percentage). The lack of a relationship between egg biochemical composition and temperature in 1999 might be due to the atypical temperature values of 1999 (Fig. 8). During the spawning season there is normally a decrease in the temperature of the water from December to March (mean $\pm \mathrm{SD}$ of $1.6 \pm 1.0^{\circ} \mathrm{C}$ obtained for 1995 to
Table 5. Sardina pilchardus. Summary of 2-way ANOVA comparing egg protein percentage as a function of sampling station and month

\begin{tabular}{|lrrrc|}
\hline Source of variation & df & MS & $F$ & p \\
\hline Sampling station & 2 & 377.1 & 4.5 & 0.013 \\
Month & 5 & 426.8 & 5.0 & 0.000 \\
Interaction & 6 & 85.0 & 1.0 & 0.423 \\
Error & 214 & 84.5 & & \\
Total & 228 & & & \\
& & & & \\
\hline
\end{tabular}

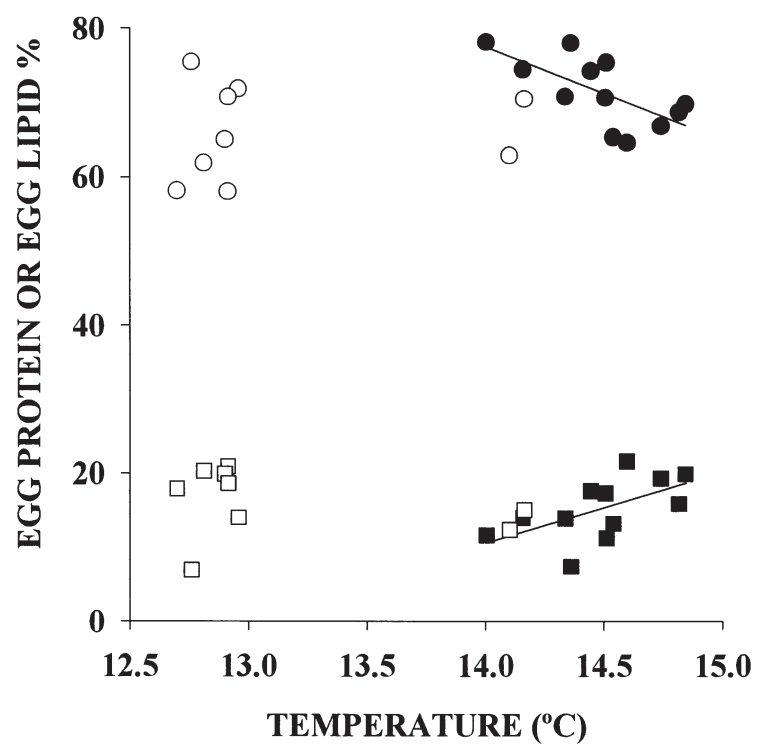

Fig. 7. Sardina pilchardus. Relationships between egg protein percentage in $1998(\bullet)$ and $1999(0)$ and egg lipid percentage in 1998 (ם) and 1999 (ㅁ) and mean temperature of the whole water column

1998), whereas in 1999 the reduction was only $0.3^{\circ} \mathrm{C}$. These atypical temperatures during the spawning season in 1999 could be explained by an upwelling process during February and March (Fig. 9).

\section{DISCUSSION}

One of the aims of this study was to gain an insight into the importance of temporal and spatial variability of spawning intensity. Our assessment was dependent on the assumption that reproductive strategy of females could be crucial in determining larval survival time. A relationship was established between egg abundance and SOC and provides a frame of reference for evaluating the importance of spatial and temporal variations in spawning. The reproductive strategy exhibited by adults of Sardina pilchardus, probably to 


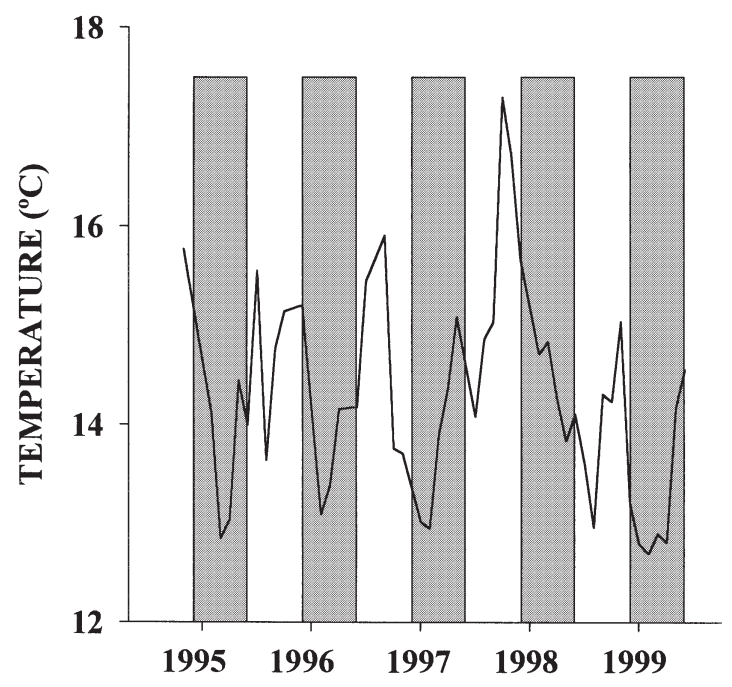

Fig. 8. Temporal variation in the mean temperature of the whole water column at Stn 14. Shaded bars show the spawning period in this area for Sardina pilchardus

assure reproductive success, seemed to be to produce a greater number of eggs in those locations and time of year in which food was more abundant. However, it is necessary to point out that eggs and seston co-occurrence observed in this study could not be due to a parental strategy, but to just some physical aggregating mechanisms. Food limitation during the larval period has been frequently hypothesised to be a major regulator of larval survival time (Cushing 1975). Canino et al. (1991) demonstrated that when spawning is not linked to the abundance of food, food densities are too low for optimal growth of first feeding larvae and this will have significant effects upon rates of feeding, growth and subsequent survival. In general agreement with this conclusion, Kucharczyk et al. (1997) and Kuyawa et al. (1997) stated that survival of larvae appears to be related to coincidence with optimal food concentrations rather than coincidence with optimal temperatures.

It has been shown that the main spawning period of sardine in Galician coastal waters is usually outside the upwelling period to minimise the loss of larvae offshore. Dickson et al. (1988) and López-Jamar et al. (1995) showed an inverse relationship between upwelling conditions and recruitment of sardine in Galician waters. The upwelling process in early spring 1999 (Fig. 9) may be responsible for the low number of eggs found at the stations that year, and survival might have been reduced by transport of eggs offshore, where food is less available (Robles et al. 1992).

There is clear evidence that during the transition to exogenous feeding, temperature is a key determinant of development and time-to-yolk absorption rates in marine fish larvae (Miranda et al. 1990, Hart \& Purser 1995, Watanabe et al. 1995, Kuyawa et al. 1997). Timeto-yolk absorption defines the period during which larvae must rely on endogenous energy reserves. Increasing temperature reduces the duration of the yolk-sac stage, which results in an earlier initiation of exogenous feeding. Our results show that when only the larvae in which the yolk-sac was fully absorbed were considered, temperature appeared to be the most important factor affecting larval survival time (Fig. 4).

However, some of the earlier larval stages died before endogenous energy reserves were exhausted. Therefore, yolk-sac reserves were not always sufficient to assure larval survival. It was observed that the percentage of larvae that died before yolk absorption was higher as egg protein percentage diminished (Fig. 5) and, furthermore, considering all larvae, larval survival time was higher as egg protein percentage increased (Fig. 6). Lein et al. (1997) suggested that temperature has a significant influence on morphological development, although variations in temperature do not appear to have any significant effect on larval size and survival. Therefore, it seems that factors other than temperature could determine larval survival (Pepin 1990). Among the hypotheses proposed to explain larval failure to successfully feed, those dealing with interspecific and intraspecific competition for food resources, or with malformations induced during incubation have received most attention (McGurk et al. 1993). Egg size has also been considered as an important factor which affects the endogenous feeding

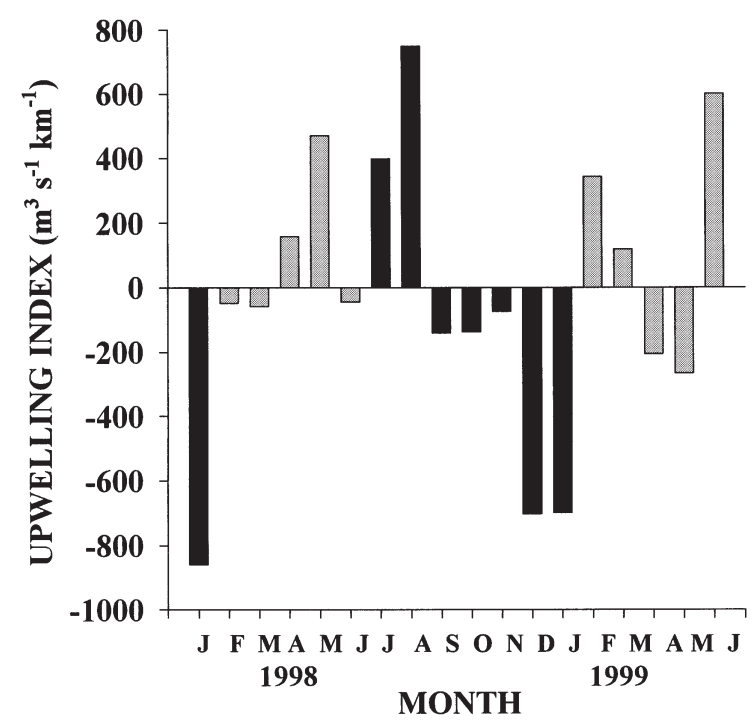

Fig. 9. Temporal variation of the upwelling index in the sampling area during 1998 and 1999. Shaded bars show the peak spawning period in this area for Sardina pilchardus. Positive values indicate upwelling and negative values indicate downwelling 
phase. It has been observed that larvae hatching from smaller eggs exhibited a poor nutritional condition earlier than those hatched from larger eggs (Baynes \& Howell 1996). However, our results show that time-toyolk absorption is not a function of egg size but a function of egg biochemical composition.

The potential usefulness of biochemical characteristics of eggs for assessing nutritional condition during embryonic and early larval development has already been pointed out by Srivastava \& Brown (1991). The use of endogenous energy reserves during fish earlylife-history stages has been reported in numerous studies. In general, either lipids (Mourente \& Vázquez 1996) or free amino acids (Rønnestad et al. 1992) have been considered to be the most important sources of energy. However, it has also been shown that larval tissues start to be metabolised when yolk-sac reserves are nearly exhausted and metabolic demands are high (Hemming \& Buddington 1988). Proteins proved to be the energy reserve being used when limiting food concentrations occurred, since a reduction in larval protein content was observed during the time of yolk-sac exhaustion and the initial stages of exogenous feeding (Canino et al. 1991). In turbot Scophthalmus maximus embryos and yolk-sac larvae, body proteins were metabolised after exhaustion of free amino acids (Finn et al. 1996).

In this study, proteins proved to be the limiting factor for sardine larval survival time, not in absolute terms but when compared to the other biochemical components of the egg (i.e. lipids and carbohydrates). Survival rates under starvation conditions were observed to increase with protein percentage in the egg and this increase was not temperature dependent (Fig. 6). However, the spatial and temporal variations observed in egg protein percentage seem to be explained by changes in temperature conditions (Fig. 7) rather than by changes in food available for the larvae. Changes in larval biochemical composition according to prevailing temperature and salinity conditions have been observed before in Sardina pilchardus (Guisande et al. 1998). As egg buoyancy has been shown as an important factor affecting recruitment in fish (Page et al. 1989, Nissling \& Westin 1991), the trade-off observed in S. pilchardus between protein and lipid content of the egg could be interpreted as a mechanism to achieve optimal larval buoyancy. The redistribution of the egg biochemical components could also be related to achieving an optimal egg development time according to prevailing temperature conditions. The lack of a relationship between egg biochemical composition and temperature in a year with an atypical evolution of water temperature (1999) caused by an upwelling process during February and March (Fig. 9) could indicate a fixed pattern of egg biochemical composition change over the spawning season in this area, where the upwelling process normally takes place between April and September (Lavin et al. 1991). However, a longer study should be necessary to corroborate the hypothesis that egg biochemical composition variation over the spawning season is a response to the normal evolution of temperature during this period in the area.

Acknowledgements. We thank D. Conway for useful comments on the manuscript, the crew of the RV 'José María Navaz' for their assistance on the cruises, and IEO of Vigo for providing the research vessel. This research was supported by the project MAR99-0328-C03-01, a grant from FUNDACIÓN PROVIGO to I.R., and a FPU grant to I.M.

\section{LITERATURE CITED}

Bailey KM, Canino MF, Napp JM, Spring SM, Brown AL (1995) Contrasting years of prey levels, feeding conditions and mortality of larval walleye pollock Theragra chalcogramma in the western Gulf of Alaska. Mar Ecol Prog Ser 119:11-23

Bakun A (1973) Coastal upwelling index, west coast of North America 1946-1971. NOAA Tech Rep NMFS, SSRF-671 US Dep Commerce

Baynes SM, Howell BR (1996) The influence of egg size and incubation temperature on the condition of Solea solea (L.) larvae at hatching and first feeding. J Exp Mar Biol Ecol 199:59-77

Bestgen KR (1996) Growth, survival, and starvation resistance of Colorado squawfish larvae. Environ Biol Fish 46: 197-209

Bisbal GA, Bengtson DA (1995) Description of the starving condition in summer flounder, Paralichthys dentatus, early life history stages. US Nat Mar Fish Serv Fish Bull 93: $217-230$

Brown RW, Taylor WW (1992) Effects of egg composition and prey density on the larval growth and survival of lake whitefish (Coregonus clupeaformis Mitchill). J Fish Biol 40:381-394

Canino MF, Bailey KM, Incze LS (1991) Temporal and geographic differences in feeding and nutritional condition of walleye pollock larvae Theragra chalcogramma in Shelikof Strait, Gulf of Alaska. Mar Ecol Prog Ser 79:27-35

Chícharo MA (1998) Nutritional condition and starvation in Sardina pilchardus (L.) larvae off southern Portugal compared with some environmental factors. J Exp Mar Biol Ecol 225:123-137

Chícharo MA, Chícharo L, Valdés L, López-Jamar E, Ré P (1998) Estimation of starvation and diel variation of the RNA/DNA ratios in field-caught Sardina pilchardus larvae off the north of Spain. Mar Ecol Prog Ser 164:273-283

Clemmensen C, Sánchez R, Wongtschowski C (1997) A regional comparison of the nutritional condition of SW Atlantic anchovy larvae, Engraulis anchoita, based on RNA/DNA ratios. Arch Fish Mar Res 45:17-43

Conway DVP, Tranter PRG, Fernández de Puelles ML, Coombs SH (1991) Feeding of larval sprat (Sprattus sprattus L.) and sardine (Sardina pilchardus Walbaum). ICES CM 1991/L:76

Craik JCA, Harvey SM (1987) The causes of buoyancy in eggs of marine teleosts. J Mar Biol Assoc UK 67:169-182 
Cushing DH (1975) Marine ecology and fisheries. Cambridge University Press, Cambridge

Dickson RR, Kelly PM, Colebrook JM, Wooster WS, Cushing DH (1988) North winds and production in the eastern North Atlantic. J Plankton Res 10:151-169

Dubois M, Gilles KA, Hamilton JK, Smith F (1956) Colorimetric method for determination of sugars and related substances. Anal Chem 28:350-356

Finn RN, Henderson JR, Fyhn HJ (1995) Physiological energetics of developing embryos and yolk-sac larvae of Atlantic cod (Gadus morhua). II. Lipid metabolism and enthalpy balance. Mar Biol 124:371-379

Finn RN, Fyhn HJ, Henderson RJ, Evjen MS (1996) The sequence of catabolic substrate oxidation and enthalpy balance of developing embryos and yolk-sac larvae of turbot (Scophthalmus maximus L.). Comp Biochem Physiol 115:133-151

Guisande C, Riveiro I, Solá A, Valdés L (1998) Effect of biotic and abiotic factors in the biochemical composition of wild eggs and larvae of several fish species. Mar Ecol Prog Ser 163:53-61

Hart PR, Purser GJ (1995) Effects of salinity and temperature on eggs and yolk sac larvae of the greenback flounder (Rhombosolea tapirina Günther, 1862). Aquaculture 136: 221-230

Hemming TA, Buddington RK (1988). Yolk absorption in embryonic and larval fishes. In: Hoar WS, Randall DJ (eds) Fish physiology, Vol 11A. Academic Press Inc, Boston, p 407-446

Jonas JL, Wahl DH (1998) Relative importance of direct and indirect effects of starvation for young walleyes. Trans Am Fish Soc 127:192-205

Kristjánsson LT, Vøllestad LA (1996) Individual variation in progeny size and quality in rainbow trout, Oncorhynchus mykiss (Walbaum). Aquat Living Resour 27:335-343

Kucharczyk D, Luczynski M, Kujawa R, Czerkies P (1997) Effect of temperature on embryonic and larval development of bream (Abramis brama L.). Aquat Sci 59:214-224

Kuyawa R, Mamcarz A, Kucharczyk D (1997) Effect of temperature on embryonic development of asp (Aspius aspius L). Pol Arch Hydrobiol 44:139-143

Lavin A, Díaz del Río G, Cabanas JM, Casas G (1991) Afloramiento en el noroeste de la Península Ibérica. Indices de Afloramiento para el punto $43^{\circ} \mathrm{N}, 11^{\circ} \mathrm{W}$. Período 1966-1989. Inf Tec Inst Esp Oceanogr 91

Lein I, Tveite S, Gjerde B, Holmefjord I (1997) Effects of salinity on yolk sac larvae of Atlantic halibut (Hippoglossus hippoglossus L.). Aquaculture 156:291-303

López-Jamar E, Coombs SH, García A, Halliday NC, Knust R, Nellen W (1995) The distribution of sardine Sardina pilchardus (Walbaum, 1792) off the north and northwestern Atlantic coast of the Iberian Peninsula, in relation to environmental conditions. Bol Inst Esp Oceanogr 11:27-46

Lowry OH, Rosenbraugh NJ, Farr AL, Randall RJ (1951) Protein measurements with the Folin phenol reagent. J Biol Chem 193:256-275

MacKenzie B, St John M, Wieland K (1996) Eastern Baltic cod: perspectives from existing data on processes affecting growth and survival of eggs and larvae. Mar Ecol Prog Ser 134:265-281

Maxwell MAK, Haas SM, Bieber LL, Tolbert NE (1978) A modification of the Lowry procedure to simplify protein determination in membrane and lipoprotein samples. Anal Biochem 87:206-210

McGurk MD, Paul AJ, Coyle KO, Ziemann DA, Haldorson LJ (1993) Relationships between prey concentration and mortality of Pacific herring, Clupea pallasi, larvae in an
Alaskan subarctic embayment. Can J Fish Aquat Sci 50: 163-180

Miranda A, Cal RM, Iglesias J (1990) Effect of temperature on the development of eggs and larvae of sardine Sardina pilchardus Walbaum in captivity. J Exp Mar Biol Ecol 140: 69-77

Mourente G, Vázquez R (1996) Changes in the content of total lipid, lipid classes and their fatty acids of developing eggs and unfed larvae of the Senegal sole, Solea senegalensis Kaup. Fish Physiol Biochem 15:221-235

Nissling A, Vallin L (1996) The ability of Baltic cod eggs to maintain neutral buoyancy and the opportunity for survival in fluctuating conditions in the Baltic Sea. J Fish Biol 48:217-227

Nissling A, Westin L (1991) Egg buoyancy of Baltic cod (Gadus morhua) and its implications for cod stock fluctuations in the Baltic. Mar Biol 111:33-35

Page F, Frank KT, Thompson KR (1989) Stage dependent vertical distribution of haddock (Melanogrammus aeglefinus) eggs in stratified water column: observations and model. Can J Fish Aquat Sci 46:55-67

Parrish RC, Nelson CS, Bakun A (1981) Transport mechanisms and reproductive success of fishes in the California current. Biol Oceanogr 1:175-203

Pepin P (1990) Effect of temperature and size on development, mortality and survival rates of the pelagic early life history stages of marine fish. Can J Fish Aquat Sci 48: 503-518

Pepin P, Orr DC, Anderson JT (1997) Time to hatch and larval size in relation to temperature and egg size in Atlantic cod (Gadus morhua). Can J Fish Aquat Sci 54:2-10

Pérez N, Porteiro C, Alvárez F (1985) Contribución al conocimiento de la biología de la sardina en Galicia. Bol Inst Esp Oceanogr 2:27-17

Pickova J, Dutta PC, Larsson PO, Kiessling A (1997) Early embryonic cleavage pattern, hatching success, and egglipid fatty acid composition: comparison between two cod (Gadus morhua) stocks. Can J Fish Aquat Sci 54: 2410-2416

Rainuzzo JR, Reitan KI, Olsen Y (1997) The significance of lipids at early stages of marine fish: a review. Aquaculture 155:103-115

Ribeiro R, Reis J, Santos C, Gonçalves F, Soares AMVM (1996) Spawning of anchovy Engraulis encrasicolus in the Mondego estuary, Portugal. Estuar Coast Shelf Sci 42: 467-482

Robles R, Porteiro C, Cabanas JM (1992) The stock of AtlantoIberian sardine: possible causes of variability. ICES Mar Sci Symp 195:418-423

Rønnestad I, Fyhn HJ, Gravningen K (1992) The importance of free amino acids to the energy metabolism of eggs and larvae of turbot (Scophthalmus maximus). Mar Biol 114: $517-525$

Rooker JR, Holt GJ, Holt SA (1997) Condition of larvae and juvenile red drum (Sciaenops ocellatus) from estuarine nursery habitats. Mar Biol 127:387-394

Solá A, Franco C, Lago de Lanzós A, Motos L (1992) Temporal evolution of Sardina pilchardus (Walb.) spawning on the N-NW coast of the Iberian Peninsula. Bol Inst Esp Oceanogr 8:97-114

Srivastava RK, Brown JA (1991) The biochemical characteristics and hatching performance of cultured and wild Atlantic salmon (Salmo salar) eggs. Can J Zool 69: $2436-2441$

Theilacker GH (1986) Starvation-induced mortality of young sea-caught jack mackerel, Trachurus symmetricus, determined with histological and morphological methods. Fish Bull US 84:1-17 
Theilacker GH, Bailey KM, Canino MF, Porter SM (1996) Variations in larval walleye pollock feeding and condition: a synthesis. Fish Oceanogr 5:112-123

Thorsen A, Kjesbu OS, Fyhn HJ, Solemdal P (1996) Physiological mechanisms of buoyancy in eggs from brackish water cod. J Fish Biol 48:457-477

Watanabe WO, Lee CS, Ellis SC, Ellis EP (1995) Hatchery

Editorial responsibility: Otto Kinne (Editor),

Oldendorf/Luhe, Germany study of the effects of temperature on eggs and yolksac larvae of the Nassau grouper Epinephelus striatus. Aquaculture 136:141-147

Zöllner N, Kirsch K (1962) Über die quantitative Bestimmung von Lipoiden (Mikromethode) mittels der vielen natürlichen Lipoiden (allen bekannten Plasmalipoiden) gemeinsamen Sulfophosphovanillin. Z Ges Exp Med 135:545-561

Submitted: July 2, 1999; Accepted: May 16, 2000

Proofs received from author(s): October 2, 2000 